\title{
Contrasting effects of dwarfing alleles and nitrogen availability on mineral concentrations in wheat grain
}

Article

Accepted Version

Gooding, M., Fan, M., McGrath, S. P., Shewry, P. R. and Zhao, F.-J. (2012) Contrasting effects of dwarfing alleles and nitrogen availability on mineral concentrations in wheat grain. Plant and Soil, 360 (1-2). pp. 93-107. ISSN 0032-079X doi: https://doi.org/10.1007/s11104-012-1203-x Available at https://centaur.reading.ac.uk/27336/

It is advisable to refer to the publisher's version if you intend to cite from the work. See Guidance on citing.

To link to this article DOI: http://dx.doi.org/10.1007/s11104-012-1203-x

Publisher: Springer

Publisher statement: The original publication is available at www.springerlink.com

All outputs in CentAUR are protected by Intellectual Property Rights law, including copyright law. Copyright and IPR is retained by the creators or other copyright holders. Terms and conditions for use of this material are defined in the End User Agreement.

www.reading.ac.uk/centaur 
Central Archive at the University of Reading

Reading's research outputs online 


\section{Contrasting effects of dwarfing alleles and nitrogen availability on mineral 2 concentrations in wheat grain}

4 Mike J. Gooding $\cdot$ Mingsheng Fan $\cdot$ Steve P. McGrath $\cdot$ Peter R. Shewry $\cdot$ Fang-Jie Zhao

8 M. J. Gooding

9 School of Agriculture, Policy and Development, The University of Reading, Earley Gate, Reading, RG6 $106 A R, U K$

\section{F. J. Zhao}

Email: Fangjie.Zhao@rothamsted.ac.uk; Fangjie.Zhao@,njau.edu.cn

Present address 
Keywords: Rht alleles $\cdot$ Wheat grain $\cdot$ Mineral concentration $\cdot$ Nitrogen fertilizer $\cdot$ Green revolution

\begin{abstract}
Background and aim Concentrations of essential minerals in plant foods may have declined in modern high-yielding cultivars grown with large applications of nitrogen fertilizer $(\mathrm{N})$. We investigated the effect of dwarfing alleles and $\mathrm{N}$ rate on mineral concentrations in wheat. Methods Gibberellin (GA)-insensitive reduced height (Rht) alleles were compared in near isogenic wheat lines. Two field experiments comprised factorial combinations of wheat variety backgrounds, alleles at the Rht-B1 locus (rht-Bla, Rht-B1b,Rht-B1c), and different $\mathrm{N}$ rates. A glasshouse experiment also included $R h t-D 1 b$ and $R h t-B 1 b+D 1 b$ in one background.

Results In the field, depending on season, Rht-B1b increased crop biomass, dry matter (DM) harvest index, grain yield, and the economically-optimal $\mathrm{N}$ rate $\left(N_{o p t}\right)$. Rht-Blb did not increase uptake of $\mathrm{Cu}, \mathrm{Fe}$, $\mathrm{Mg}$ or $\mathrm{Zn}$ so these minerals were diluted in grain. Nitrogen increased DM yield and mineral uptake so grain concentrations were increased ( $\mathrm{Fe}$ in both seasons; $\mathrm{Cu}, \mathrm{Mg}$ and $\mathrm{Zn}$ in one season). Rht-Blb reduced mineral concentrations at $N_{\text {opt }}$ in the most $\mathrm{N}$ responsive season. In the glasshouse experiment, grain yield was reduced, and mineral concentrations increased, with $R h t$ allele addition.

Conclusion Effects of Rht alleles on $\mathrm{Fe}, \mathrm{Zn}, \mathrm{Cu}$ and $\mathrm{Mg}$ concentrations in wheat grain are mostly due to their effects on DM, rather than of GA-insensitivity on $N_{o p t}$ or mineral uptake. Increased $\mathrm{N}$ requirement in semi-dwarf varieties partly offsets this dilution effect.
\end{abstract}




\section{Introduction}

Deficiencies of the micronutrients iron $(\mathrm{Fe})$ and zinc $(\mathrm{Zn})$ affect more than 2 billion people worldwide (WHO 2002). Other minerals such as magnesium $(\mathrm{Mg})$ and copper $(\mathrm{Cu})$ may also be inadequate in the diet of some people (White and Broadley 2009). Cereals are an important source of minerals in the human diet; providing $44 \%$ of the daily intake of $\mathrm{Fe}, 27 \%$ of $\mathrm{Mg}, 25 \%$ of $\mathrm{Zn}$ and $31 \%$ of $\mathrm{Cu}$ in the UK adult population (Henderson et al. 2003). There are concerns that the concentrations of essential minerals in plant foods may have declined as a result of increased yield (Davis et al. 2004; Garvin et al. 2006; White and Broadley 2005). Analysis of the archived wheat grain samples from the Broadbalk long-term experiment at Rothamsted has shown that the concentrations of $\mathrm{Fe}, \mathrm{Zn}, \mathrm{Cu}$ and $\mathrm{Mg}$ have all declined since the 1960s, coinciding with the introduction of modern short-straw cultivars (Fan et al. 2008).

Rapid increases in wheat yields in major wheat growing areas of the world from the 1960s through to the 1990's were associated with a reduction in wheat stature. This shortening was accompanied by an increase in dry matter harvest index, and also permitted sufficient nitrogen $(\mathrm{N})$ fertilizer to be applied to the crop without the crop lodging such that canopy size could be optimized for capture of photosynthetically active radiation, and thus biomass yield (Gooding 2009). In the UK during the 1970s and 1980s yield increases were concurrent with final crop heights declining to around an apparently optimal stature of between 800 and $900 \mathrm{~mm}$ (Flintham et al. 1997; Austin 1999). Reductions in height were achieved either by the combined effect of many minor genes, and/or by the inclusion of major genes for reduced height $(R h t)$. The commonly used $R h t-B 1 b$ and $R h t-D 1 b$ (previously named $R h t 1$ and $R h t 2$ ) semi-dwarfing alleles from the Japanese wheat 'Norin 10' reduce sensitivity to endogenous gibberellins (GA) (Murase et al. 2008), and individually often reduce height by about 15\% (Addisu et al. 2010). In the UK, Rht-D1b has been widely used in elite lines since the 1970's (e.g. cvs. Hobbit (1977) and Mardler (1978) were early examples (Austin et al. 1980)), although $R h t-B 1 b$ has also been used more recently (e.g. cv. Robigus). More potent alleles, conferring severe dwarfism ( $>30 \%$ height reduction) are available e.g. Rht-Blc (previously Rht3) from 'Tom Thumb' (Borner et al. 1997). The last widely used winter wheat cultivar suited for bread-making in the UK which did not have a major semi-dwarfing gene was cv. Mercia (introduced in 1983). Despite the lack of an Rht allele, the height of Mercia can be considered to be within the range commonly observed for modern commercial releases in the UK, that have an Rht allele (Gooding et al. 2012).

There is little information as to whether the reductions seen in mineral concentrations in UK wheat are due to effects of gibberellin insensitivity conferred by the adoption of the Norin 10 semi-dwarfing alleles, or due to yield increases associated with shortening per se. Here we use near isogenic lines varying for GA sensitivity conferred by alleles at the Rht-Bl locus (rht-Bla (tall); Rht-B1b (semi-dwarf); 
Rht-Blc (severe dwarf) in backgrounds that vary for height (Mercia, Maris Widgeon (1964) and Maris Huntsman (1969)) in three different environments: field plots in two contrasting seasons, and pots under glass (the Maris Huntsman series only).

Adoption of semi-dwarfing alleles increases the amount of $\mathrm{N}$ fertilizer that can be justified to be applied by farmers on economic grounds (Loddo and Gooding 2012). Nitrogen availability has a significant impact on mineral uptake and partitioning to, and concentrations in, the grain (Cakmak et al. 2010; Kutman et al. 2011a, b). To more fully evaluate the impact of the adoption of semi-dwarf cultivars on the mineral concentrations on UK wheat it is, therefore, necessary to investigate any interaction between dwarfing alleles and $\mathrm{N}$ fertilizer application rate, and more specifically, to evaluate mineral concentrations at the economically optimal $\mathrm{N}$ rate for individual lines.

The aim of the present study was to quantify the effects of dwarfing alleles and the application rate of $\mathrm{N}$ on the uptake of minerals and their concentrations in grain, especially $\mathrm{Fe}, \mathrm{Zn}, \mathrm{Cu}$ and $\mathrm{Mg}$ which are often inadequate in the diet.

\section{Materials and methods}

Field experiments

Plots of winter wheat were maintained on a free-draining sandy loam soil ( $9 \%$ clay, particle size $<0.2 \mu \mathrm{m}$; $19 \%$ silt, $2-20 \mu \mathrm{m} ; 72 \%$ sand, $20-2000 \mu \mathrm{m}$ ) overlying coarse red-brown sand, principally of the Sonning series (Jarvis, 1968), at the Crop Research Unit, University of Reading, UK (51 ${ }^{\circ} 29^{\prime} \mathrm{N}, 0^{\circ} 56^{\prime} \mathrm{W}, 35 \mathrm{~m}$ above sea level), in the 2009/10 and 2010/11 growing seasons. In both seasons, the experiments followed a three year rye grass and chicory ley, destroyed with glyphosate before mouldboard ploughing to 300 $\mathrm{mm}$ (Table 1). Before cultivation, the soil was tested for $\mathrm{pH}$, phosphorous, potassium and magnesium availability (Anon. 1986; Anon. 2010; Table 1) and corrective nutrients applied accordingly. Following cultivation in autumn, total soil carbon and mineral $\mathrm{N}$ content $(0-900 \mathrm{~mm})$ averaged $0.69 \% \mathrm{DM}$ and 55 $\mathrm{kg} \mathrm{N} / \mathrm{ha}$ respectively. Soil mineral $\mathrm{N}$ content in the following February averaged $35 \mathrm{Kg} \mathrm{N} / \mathrm{ha}$. For this rotational position at this site over five previous seasons the $\mathrm{N}$ uptake by the above ground wheat receiving full crop protection but no $\mathrm{N}$ fertilizer averaged $75 \mathrm{~kg} \mathrm{~N} /$ ha, i.e. a soil $\mathrm{N}$ supply index of 1 (Anon. 2010). Crop husbandry was indicative of local commercial practice (Table 1), and achieved a high level of control of weeds, pests and diseases. Rainfall and air temperature were recorded at an automatic weather station within $400 \mathrm{~m}$ of the experiments (Table 1). 
Near isogenic lines (NILs) comprised a factorial combination of background varieties (Maris Huntsman, Maris Widgeon and Mercia in 2009/10 and just Maris Widgeon and Mercia in 2010/11) and three alleles at the Rht-B1 locus: rht-BIa (tall), Rht-B1b (semi-dwarf, syn. Rht1) and Rht-B1c (severedwarf, syn. Rht3). Untreated seeds $\left(300 / \mathrm{m}^{2}\right)$ were drilled into $120 \mathrm{~mm}$ rows in $2 \times 6 \mathrm{~m}$ sub-plots, separated by a $500 \mathrm{~mm}$ double track wheeling. Main plots, randomized in three complete blocks, comprised the background $\mathrm{x}$ allele combinations; each contained randomized sub-plots allocated to receive different rates of $\mathrm{N}$ fertilizer applied as granular ammonium nitrate. In 2009/10 the total $\mathrm{N}$ rates were $0,100,200$ and $350 \mathrm{~kg} \mathrm{~N} / \mathrm{ha}$. For the three sub-plots receiving N, 50kg N/ha was applied at the first node detectable growth stage (GS 31, Zadoks et al. 1974) and again at flag leaf emergence (GS 39). The 200 and $350 \mathrm{~kg} \mathrm{~N} /$ ha treatments received a further 100 and $250 \mathrm{~kg} \mathrm{~N} /$ ha respectively at the second node stage (GS 32). In 2010/11 the total $\mathrm{N}$ rates were $0,50,100,200,350$ and $450 \mathrm{~kg} \mathrm{~N} /$ ha applied in equal splits at GS 31 and 33.

Crop height was measured five days before harvest with a polystyrene rising disc (Addisu et al. 2009). During the week before harvest, above ground whole crop rows either side of three randomly placed $0.5 \mathrm{~m}$ lengths (total area equivalent of $0.36 \mathrm{~m}^{2}$ ) were collected from each subplot. Samples were partitioned into grain, chaff and straw. After oven drying at $80^{\circ} \mathrm{C}$, dry weight of each component was estimated and mineral content assessed. Plot combine harvesting was with a $1.4 \mathrm{~m}$ cutter bar such that effective separation of subplots was $0.8 \mathrm{~m}$ to reduce edge effects. Information from sample areas was used to calculate harvest indices of dry matter and minerals.

Pot experiment

Soil $(0-200 \mathrm{~mm})$ was collected from the Rothamsted farm, air dried and sieved through a $5 \mathrm{~mm}$ sieve. Plastic pots (200 mm diameter) were filled with $3.5 \mathrm{~kg}$ air-dried soil each. Fertilizers $\left(0.7 \mathrm{~g} \mathrm{~N}\right.$ as $\mathrm{NH}_{4} \mathrm{NO}_{3}$ and $0.175 \mathrm{~g} \mathrm{P}$ as $\mathrm{KH}_{2} \mathrm{PO}_{4}$ ) were mixed into the soil. Seeds of the NILs of different Rht alleles (rhtBla/Dla, Rht-B1b, Rht-D1b, Rht-B1b+D1b, Rht-B1c) in the Maris Huntsman background were germinated on perlite and vernalized at $5^{\circ} \mathrm{C}$ in a controlled environment room for 8 weeks. Seedlings were then transplanted into the soil (5 per pot). Each NIL was planted in four pots. Pots were placed on benches in a randomized block design inside a glasshouse lit with sunlight supplemented with sodium vapor lamps to maintain a light intensity of $>350 \mu \mathrm{mol} / \mathrm{m}^{2} / \mathrm{s}$. Plants were watered daily with deionized water to approximately $70 \%$ of the water holding capacity. At maturity, plants were harvested by cutting at $1 \mathrm{~cm}$ above the soil surface. Grain was separated from the straw and dried at $80^{\circ} \mathrm{C}$ for $48 \mathrm{~h}$. 
Grain and straw were ground to fine powder and digested with $\mathrm{HNO}_{3} / \mathrm{HClO}_{4}(85 / 15, \mathrm{v} / \mathrm{v})$ in a heating block (Zhao et al. 1994). The concentrations of minerals, including the major nutrients K, P, S, Ca and $\mathrm{Mg}$, the micronutrients $\mathrm{Fe}, \mathrm{Zn}, \mathrm{Cu}$ and $\mathrm{Mn}$, and the soil contamination indicator mineral $\mathrm{Ti}$, were determined using inductively-coupled plasma atomic emission spectrometry. A certified reference material (NIST 1567a wheat flour) was included in the analysis for quality assurance. The results obtained were in good agreement with the certified values; mean and standard deviation from 18 digestion repeats were $14.6 \pm 1.5 \mathrm{mg} / \mathrm{kg}$ for Fe (certified value $14.1 \pm 0.5$ ), $2.3 \pm 0.2 \mathrm{mg} / \mathrm{kg}$ for Cu (certified value $2.1 \pm 0.2), 12.6 \pm 0.8 \mathrm{mg} / \mathrm{kg}$ for $\mathrm{Zn}$ (certified value $11.6 \pm 0.4$ ) and $386 \pm 9 \mathrm{mg} / \mathrm{kg}$ for $\mathrm{Mg}$ (certified value $400 \pm 2$ ). Nitrogen concentration was determined with the Dumas combustion method (LECO FP-328, LECO, Stockport, UK).

Statistical analysis

161

For the field experiments, appropriate split plot analyses of variance (ANOVA) included a treatment structure of Background*Allele*pol(N rate;3) (GENSTAT 13; VSN International, Hemel Hempstead, $\mathrm{UK}$ ) so as to split $\mathrm{N}$ effects into polynomial contrasts. Titanium (Ti) on the above-ground crop (straw+chaff+grain) was used as a covariate for above ground yields and harvest indices of DM and minerals to help correct for error associated with any soil contamination. The effect of the covariate was significant $(P<0.05)$ in all these cases. Ti has been used as an indicator of soil contamination because it is abundant in soil but hardly taken up by plants (Cook et al. 2009). There were no significant effects of the covariate on any assessments of the grain (yields, mass per grain, and concentration) and therefore, the covariate was omitted from grain ANOVAs. There was little evidence of Background $\mathrm{x}$ Allele $\mathrm{x} \mathrm{N}$ rate interactions so data are presented for the two factor interactions including $\mathrm{N}$ rate. The economically optimal level of $\mathrm{N}$ fertilizer was calculated on the simple basis of the $\mathrm{N}$ rate fitted to give the greatest financial margin over $\mathrm{N}$ cost. These calculations were based on $\mathrm{N}$ :grain price ratios of 5:1 and 10:1 (Sylvester-Bradley and Kindred 2009) with grain traded on a 15\% moisture content basis. Grouped polynomial regression analysis was employed to assess the relationships between mineral and $\mathrm{N}$ concentrations. For the pot experiment, ANOVA was performed to test the significance of the differences between the NILs.

\section{Results}


The 2009/10 growing season was characterized by comparatively dry conditions during stem extension (April and May; Table 1) and grain filling (June and July).

Averaged over background and $\mathrm{N}$ rate, the inclusion of the Norin 10 semi-dwarfing $R h t-B 1 b$ allele produced crop heights in the $800-900 \mathrm{~mm}$ range i.e. that predicted to be optimal for yield (Table 2). The rht-B1a and Rht-B1c alleles were associated with crop heights which would be considered to be supraand sub- optimal respectively. Rht-B1b increased grain yield of DM (Fig. 1c) because it increased both above-ground crop biomass (Fig. 1a), and harvest index (Fig. 1b). Relative to rht-B1a (tall), Rht-B1b was associated with significantly $(P<0.05)$ reduced concentrations of $\mathrm{Cu}$ in grain (Fig. 1 ; ; Main Effect $=-2.6$ $\mathrm{mg} / \mathrm{kg}$; s.e.d. $=0.0768$ (d.f.=16)), Fe (Fig. $1 n ;-2.7 ; 0.71)$, Mg (Fig. 1s; -98.4; 12.77), and Zn (Fig. 1x; 2.6; 0.50). Rht-B1b also significantly reduced the concentrations of $\mathrm{N}$ (Fig. 2), manganese (Mn), phosphorous $(\mathrm{P})$, and sulfur $(\mathrm{S})$, but not of calcium $(\mathrm{Ca})$, potassium $(\mathrm{K})$, molybdenum $(\mathrm{Mo})$ or sodium (Na) (data not presented). The decreased concentrations of $\mathrm{Cu}, \mathrm{Fe}, \mathrm{Mg}$ and $\mathrm{Zn}$ can only be ascribed to dilution due to increased yields of dry matter, as there was no significant effect of $R h t-B 1 b$ on total mineral uptake, whether expressed in terms of the above ground biomass or grain per unit area, or on a per grain basis (Fig. 1).

Rht-B1c improved harvest index relative to Rht-B1b (Fig. 1b) but this was insufficient to counter a

200

201

202

203 negative effect on above ground biomass (Fig. 1a), such that severe dwarfing was associated with reduced grain yields (Fig. 1c). Rht-B1c was not, however, significantly $(\mathrm{P}>0.05)$ detrimental to the accumulation of $\mathrm{Cu}$ (Fig. 1e,g), Fe (Fig. $1 j, l$ ), or $\mathrm{Zn}$ (Fig. $1 t, v$ ) so relative to Rht-B1b, the grain concentrations of all three mineral were increased (Fig. $1 i, n$ ). For Mg, as for other minerals, Rht-Blc did not influence uptake into the above-ground crop (Fig. 1o). In contrast to effects on DM, however, severe dwarfing was associated with a reduced harvest index of $\mathrm{Mg}$ (Fig. $1 p$ ) such that the yields of $\mathrm{Mg}$ per grain were reduced by Rht-B1c (Fig. 1q), contributing to reduced concentrations of Mg in the grain (Fig. 1s).

In the absence of Rht, the height of Mercia would be considered optimal and Maris Widgeon supraoptimal (Table 2). The two shorter cultivars had the highest DM harvest indices and apparently, also the higher grain yields ( $P=0.044$ for the main effect of background). Similar to the results for $R h t-B 1 b$, there was no significant effect of background on mineral uptake $(\mathrm{Cu}, \mathrm{Fe}, \mathrm{Mg}$ or $\mathrm{Zn})$ into the above-ground biomass, and mineral concentrations tended to be more dilute in Mercia compared with Maris Widgeon (Table 2, $P<0.001,0.077,<0.001$ for the main effects of background on $\mathrm{Cu}, \mathrm{Mg}$ and $\mathrm{Zn}$ respectively). Additional effects of cultivar were, however, evident: the harvest indices and grain yields per unit area for 
all four minerals varied significantly among the backgrounds, and were always highest for Maris Huntsman (Table 2).

In contrast to the effects of $R h t-B 1 b$ which diluted mineral concentrations as grain yields of dry matter were increased, $\mathrm{N}$ rate was associated with both increased grain DM yields, and increased concentrations of $\mathrm{Cu}$ and $\mathrm{Fe}$. The quantity of Fe per grain was also increased by $\mathrm{N}$ applications (Fig. 1h, $m, r, w)$ even though such applications also reduced mean grain weight (Fig. 1d). Nitrogen application increased the quantities of all four minerals in the above ground crop biomass (Fig. 1e, $j, o, t$ ), which largely explains similar effects on quantities in the grain on a unit area basis (Fig. $1 g, l, q, v$ ), although $\mathrm{N}$ application also increased the harvest index of Fe (Fig. 1k). There was a strong association between the grain Fe concentration and that of grain N (Fig. 2); to the extent that when grain $\mathrm{N}$ concentration was included in the regression model, there was no statistical justification for including effects of Allele as an explanatory factor. This was not the case for $\mathrm{Cu}, \mathrm{Mg}$ and $\mathrm{Zn}$ (Fig. 2).

The economically optimal level (Table 3 ) of $\mathrm{N}$ fertilizer varied with allele because there was a significant Allele $\mathrm{x} \mathrm{N}$ rate interaction on grain yield of DM (Fig. 1c). The grain yield of $R h t-B 1 b$ was the most responsive to $\mathrm{N}$ (Fig. 1c), partly because of a combination of comparatively high biomass yield (Fig. $1 a$ ) and harvest index (Fig. $1 b$ ) at the highest $\mathrm{N}$ rate. Using the quadratic fits in Fig. $1 c, N_{\text {opt }}$ was between 40 and $50 \mathrm{~kg} \mathrm{~N} / \mathrm{ha}$ higher for Rht-B1b compared with rht-Bla (Table 3). Despite the benefit of $\mathrm{N}$ application for some mineral concentrations, however, this level of increase in $\mathrm{N}$ application was insufficient to compensate for the diluting effect of $R h t-B 1 b$ (Table 3) i.e. semi-dwarfing reduced the concentrations of all four minerals whether compared at a single average $\mathrm{N}$ rate, or at the different $N_{\text {opt }}$ for the different alleles. Increasing $\mathrm{N}$ cost relative to grain value reduced $N_{\text {opt }}$ and therefore tended to reduce Fe concentration at $N_{\text {opt }}$.

Field experiment 2010/11

Conditions were particularly dry during the start of stem extension (March and April, Table 1), and also exceptionally warm during April. The period of below average rainfall continued in May. The grain filling period (June and July) was associated with above average rainfall and comparatively cool temperatures. The notably dry conditions during spring, coinciding with the timing of the $\mathrm{N}$ application, probably contributed to plants being shorter than in the previous season (Tables 2 and 3), and also to the crop being much less $\mathrm{N}$ responsive in terms of above ground biomass and grain yield (Fig. $3 a$,c). In contrast to the previous year, crop heights of rht-Bla would not be considered excessive for optimizing grain yields (Table 2). Also in contrast to 2009/10, there were no significant main effects of Rht-B1b on above-ground dry matter or grain yield despite a small positive effect on harvest index (Fig. $3 a, b, c$ ). 
Relative to rht-Bla (tall), the size of effects of $R h t-B 1 b$ on grain mineral concentrations were much reduced compared with the previous year. Indeed, for the 2011 harvest there was no statistically significant main effect of Rht-Blb on the grain concentrations of Cu, Fe, Zn (Fig. 3i, n, x), Ca, Mn, Na or $\mathrm{S}$ (data not presented). Rht-Blb was associated with small but significant reductions in the concentrations of $\mathrm{Mg}$ (Fig. 1s; Main Effect = -31 mg/kg; s.e.d. = 9.6 (d.f.=16)), N (Fig. 2; -0.84; 0.366) and P (-110; 35), and an increase in the concentration of $\mathrm{K}(+139 ; 34.1)$. Where effects were statistically significant, it is difficult to ascribe these directly to effects on dilution with DM, mineral uptake, or partitioning given the very marginal effects of $R h t-B 1 b$ on any of these variables.

As in 2010, Rht-B1c improved harvest index relative to Rht-B1b (Fig. $3 b$ ) but in 2011 this was sufficient to counter the negative effect on above ground biomass (Fig. $3 a$ ), such that severe dwarfing was associated with comparable grain yields to taller lines, when taking the averages over $\mathrm{N}$ rates (Fig. $3 c$ ). As well as above ground dry matter accumulation $R h t-B 1 c$ was detrimental to the accumulation of $\mathrm{Mg}$ (Fig. $3 o$ ) and $\mathrm{Zn}$ (Fig. 3t), particularly at high rates of $\mathrm{N}$ fertilizer. In contrast to the situation with DM, Rht-B1c did not increase the harvest index of minerals, and this failure contributed to the reduction in concentration of $\mathrm{Mg}$ in the grain (Fig. $3 s$ ).

In 2011, grain yields of Mercia tended to be higher than Maris Widgeon, associated with significantly reduced crop height and increased DM harvest index (Table 3). Harvest index of Cu was increased in Mercia, but this was insufficient to prevent a dilution of $\mathrm{Cu}$ in the grain. $\mathrm{Zn}$ was also more dilute in Mercia grain, again not because of reduced uptake or partitioning, but because effects did not match those on DM.

As in 2010, uptake of $\mathrm{Cu}, \mathrm{Fe}, \mathrm{Mg}$ and $\mathrm{Zn}$ increased with $\mathrm{N}$ rate, both in the above ground biomass and in the grain (Fig. 3). Increases in mineral quantity in the grain tended to be greater than the grain DM yield response to $\mathrm{N}$ application such that, for at least part of the range of rates used, mineral concentration increased with $\mathrm{N}$ application: for $\mathrm{Cu}$ to about $100 \mathrm{~kg} \mathrm{~N} / \mathrm{ha}$ (Fig. $3 i$ ); for $\mathrm{Fe}$ and $\mathrm{Mg}$, to about $300 \mathrm{~kg} \mathrm{~N} / \mathrm{ha}$ (Fig. 3n, s); and for $\mathrm{Zn}$ to about $400 \mathrm{~kg} \mathrm{~N} / \mathrm{ha}$ (Fig. 3x). The concentration of $\mathrm{Fe}$ in the grain was again closely associated with $\mathrm{N}$ concentration (Fig. 2). There were also positive relationships between grain $\mathrm{N}$ concentration and the concentrations of $\mathrm{Mg}$ and $\mathrm{Zn}$, but not to the extent that $\mathrm{N}$ concentration could account for $R h t$ allele effects.

Although there was no main effect of $R h t$ allele on grain DM yield, there was a significant Allele $\mathrm{x} \mathrm{N}$ rate interaction (Fig. $3 c$ ). Rht-Blb was again the most N-responsive allele, having a comparatively low yield at low $\mathrm{N}$ rates, but the highest yield at high $\mathrm{N}$ rates. The derived $N_{\text {opt }}$ for a 5:1 N:grain price ratio suggested that it would have been justified to apply $64 \mathrm{~kg}$ more $\mathrm{N} /$ ha on Rht-B1b than on $r h t-B 1 a$ (Table 4). Given the shallow response of grain yield to $\mathrm{N}$ in this season, however, the statistical error around this figure must be substantial. Nonetheless, if an extra $64 \mathrm{~kg} \mathrm{~N}$ was applied to $R h t-B 1 b$ this would have been 
sufficient to negate the diluting effect of the allele on the $\mathrm{Mg}$ concentration in the grain. It should also be noted, however, that the grain yield response was so shallow, that there was no economic justification for applying any $\mathrm{N}$ fertilizer to any allele if the $\mathrm{N}$ :grain price ratio was as high as 10:1 (Table 4), and hence the diluting effect of $R h t-B 1 b$ on $\mathrm{Mg}$ concentration would have persisted at high $\mathrm{N}$ cost.

Pot experiment

Both plant height and grain yield decreased with the introduction of dwarfing alleles in the Maris Huntsman background in the order of rht-Bla/Dla (tall) $>$ Rht $B 1 b>R h t-D 1 b>R h t-B 1 B+D 1 b>R h t B 1 c$ (Fig. 4a). In contrast to the field experiments, $R h t-B 1 b$ did not increase the grain yield compared with $r h t-$ Bla/Dla (tall). Plant heights of all lines were substantially shorter than the corresponding ones in the field experiments.

The concentrations of $\mathrm{Fe}, \mathrm{Zn}$ and $\mathrm{Cu}$ differed significantly $(P<0.001)$ between the dwarfing alleles, but, in contrast to the field experiments, they increased with the severity of the dwarfing phenotype (Fig. $4 \mathrm{~b})$. Note that the concentrations of $\mathrm{Fe}$ and $\mathrm{Zn}$ were considerably larger than those from the field trial. In addition to the three minerals presented here, the concentrations of $\mathrm{Mg}, \mathrm{P}$ and $\mathrm{S}$ also showed significant increasing trends with the degree of dwarfing (data not shown). There were highly significant negative correlations between the concentrations of $\mathrm{Fe}, \mathrm{Zn}$ or $\mathrm{Cu}$ and grain yield $(r=-0.80,-0.79$ and -0.71 for $\mathrm{Fe}$, $\mathrm{Zn}$ and $\mathrm{Cu}$, respectively, $P<0.001$; Fig. 5). The amounts of $\mathrm{Fe}, \mathrm{Zn}$ and $\mathrm{Cu}$ taken up by the plants (straw and grain) did not differ significantly between the different $R h t$ alleles (Fig. 4c), nor were there any significant differences in the amounts of these minerals contained in the grain (data not shown). The harvest indices for both the biomass and the three minerals were broadly similar, showing a decreasing trend with the dwarfing severity (Fig. 4d).

\section{Discussion}

We confirm the shortening effects of alleles at the Rht-B1 and Rht-D1 loci (Flintham et al. 1997). Also consistent with previous studies, we find semi-dwarfing is beneficial for grain yield when it reduces final crop height to around 800-900 mm in UK conditions (Flintham et al. 1997; Austin 1999), and that semidwarfing increases the response to $\mathrm{N}$ fertilizer in such circumstances (Anderson et al. 1991). That Rht$B 1 c$ reduces grain yield because increases in harvest index are insufficient to compensate for reductions in above ground biomass was also reported by Flintham et al. (1997). The glasshouse pot experiment here was consistent with other studies where semi-dwarfing with $R h t$ alleles have had neutral or negative 
effects on yield in situations where $r h t-B 1 a / D l a$ is associated with plant heights already optimal or suboptimal for yield (Flintham et al. 1997; Chapman et al. 2007; Gooding et al. 2012).

The main objective of the present study was to test if the introduction of the GA-insensitive dwarfing alleles in wheat affects the concentrations of minerals in grain that are particularly important for human nutrition. Our results suggest that the dwarfing alleles have comparatively little direct effects on the uptake and translocation to grain of $\mathrm{Fe}, \mathrm{Zn}, \mathrm{Cu}$ and $\mathrm{Mg}$; however, the concentrations of these minerals in grain were affected indirectly mainly as a result of the changes in grain yield. That the dilution of minerals by the incorporation $R h t-B 1 b$ was not due to more direct physiological effects of gibberellin insensitivity is further supported by: a lack of progression of effects through rht-Bla to Rht-B1b to Rht$B 1 c$ on mineral concentration despite the progression in GA insensitivity and degree of dwarfing; the contrasting effects of $R h t$ alleles in the two field experiments, and between the field and pot experiments, consistent with the contrasting effects on grain yield; and a similar dilution of minerals between Maris Widgeon and Mercia, associated with reduced height but not mediated through differences in GAsensitivity.

Consistent with the effects of Rht-B1b and Mercia in the field, mineral (e.g. Zn, Fe or Mg) concentrations have been found to correlate negatively with grain yield among diverse wheat cultivars (McDonald et al. 2008; Morgounov et al. 2007; Oury et al. 2006; Zhao et al. 2009). The decreasing trend of mineral concentrations in wheat grain, either with the cultivar release date (Garvin et al. 2006; Zhao et al. 2009) or in the Broadbalk long-term experiment (Fan et al. 2008), can be largely attributed to the dilution effect brought about by increased grain yield. This effect may arise because the distribution of minerals to grain does not match the increased biomass allocation to grain in the higher yielding cultivars.

Whilst yield gain through cultivar improvement results in a dilution of mineral concentrations in wheat grain, yield increase in response to increasing the application rate of $\mathrm{N}$ did not. In fact, increasing $\mathrm{N}$ rate increased the concentrations of $\mathrm{Fe}$ and, depending on season and to a lesser extent, $\mathrm{Cu}, \mathrm{Mg}$ and $\mathrm{Zn}$ in grain. Similar effects have been reported for Fe and $\mathrm{Zn}$ in durum (Triticum durum) and bread (McGrath 1985; Cakmak et al. 2010; Shi et al. 2010) wheats. Increasing N supply was found to increase the uptake, root-to-shoot translocation and remobilization from vegetative tissues to grain of $\mathrm{Zn}$ and Fe in durum wheat, possibly because of more transporter proteins and an increased pool of nitrogenous chelators (e.g. nicotianamine) that are important for the phloem transport of these metals (Kutman et al. 2011a,b). Our results relating grain mineral concentration to grain $\mathrm{N}$ concentration suggest that any effect of plant $\mathrm{N}$ compounds on $\mathrm{Fe}$ is much more direct than that for $\mathrm{Cu}$ or $\mathrm{Zn}$. Our results would suggest that the benefits of $\mathrm{N}$ rate for $\mathrm{Zn}$ are more reliable as grain $\mathrm{N}$ concentrations exceed $20 \mathrm{~g} \mathrm{~N} / \mathrm{kg}$. Grain $\mathrm{N}$ concentrations were in a lower range in the 2009-10 than in the 2010-11 trial, which may explain the lack of a significant $\mathrm{N}$ effect on grain $\mathrm{Zn}$ in the former season. 
We demonstrate that the greater yield responses of appropriately-statured cultivars justify the use of larger $\mathrm{N}$ rates. This has the effect of offsetting some of the dilution effect on grain mineral concentration

\section{1}

352

353

354

355

356

357

358

359

360

361

362

363

364

365

366

367

368

369

370

371

372

373

374

375

376

377

378

379 but at the economically optimal level of $\mathrm{N}$ the concentrations of minerals were still about $10 \%$ lower for the semi-dwarf Rht-Blb allele than in the tall allele in the most responsive field season of 2009/10 (Table 3). It is well known, however, that wheat responses to $\mathrm{N}$ rate, and its interaction with genotype varies with site and season, so further experiments would be necessary to quantify this offset more generally. Our field experiments were conducted in two comparatively dry seasons for the site, which would be expected to reduce the wheat response to $\mathrm{N}$ (Gooding 2009). A comparison of the two seasons reported here strongly supports the importance of adequate moisture for large responses of wheat grain yield to $\mathrm{N}$ rate. The comparison also suggests that offsetting of the $R h t-B 1 b$ mediated dilution of minerals with the extra $\mathrm{N}$ fertilizer is less likely in wetter seasons. Future benefits of $\mathrm{N}$ for mineral concentrations (particularly for $\mathrm{Fe}$ ) are likely to be curtailed if increased cost and restriction of $\mathrm{N}$ fertilizer continues, and/or genetic improvements in N utilization efficiency (crop DM / crop N; Gooding et al. 2012) are realized. There is, therefore, increasing need to explore further the genetic variability in grain mineral concentration to achieve both high yields and sufficient levels of minerals in wheat (White and Broadley 2009; Zhao et al. 2009).

\section{Acknowledgements}

The authors are grateful to Mr RJ Casebow and Mr S Loddo for technical assistance for the field experiments, to Mr A Crosland for ICP analysis and to the John Innes Centre for providing the seeds. Rothamsted Research receives strategic funding from the Biotechnology and Biological Sciences Research Council of the UK. M. S. Fan was supported by a Rothamsted International Fellowship.

\section{References}

Addisu M, Snape JW, Simmonds JR, Gooding MJ (2009) Reduced height (Rht) and photoperiod insensitivity $(P p d)$ allele associations with establishment and early growth of wheat in contrasting production systems. Euphytica 166:249-263 
Addisu M, Snape JW, Simmonds JR, Gooding MJ (2010) Effects of reduced height (Rht) and photoperiod insensitivity $(P p d)$ alleles on yield of wheat in contrasting production systems. Euphytica 172:169181

Anderson WK, Seymour M, D'Antuono MF (1991) Evidence for differences between cultivars in responsiveness of wheat to applied nitrogen. Aust J Agric Res 42: 363-377.

Anon. (1986) The Analysis of Agricultural Materials, MAFF Reference Book 427, 3rd edn. HMSO, London.

Anon. (2010) Fertiliser Manual (RB209) 8th edn. TSO, Norwich.

Austin RB (1999) Yield of wheat in the United Kingdom: Recent advances and prospects. Crop Sci 39:1604-1610

Austin RB, Bingham J, Blackwell RD, Evans LT, Ford MA, Morgan CL, Taylor M. (1980) Genetic improvements in winter-wheat yields since 1900 and associated physiological changes. J Agric Sci 94:675-689

Borner A, Roder M, Korzun V (1997) Comparative molecular mapping of GA insensitive Rht loci on chromosomes 4B and 4D of common wheat (Triticum aestivum L.). Theor Appl Genet 95:1133-1137

Cakmak I, Pfeiffer WH, McClafferty B (2010) Biofortification of durum wheat with zinc and iron. Cereal Chem 87:10-20.

Chapman SC, Mathews KL, Trethowan RM, Singh RP (2007) Relationships between height and yield in near-isogenic spring wheats that contrast for major reduced height genes. Euphytica 157:391-397

Cook LL, McGonigle TR, Inouye RS (2009) Titanium as an indicator of residual soil on arid-land plants. J Environ Qual 38:188-199.

Davis DR, Epp MD, Riordan HD (2004) Changes in USDA food composition data for 43 garden crops, 1950 to 1999. J Am Coll Nutr 23:669-682

Fan MS, Zhao FJ, Fairweather-Tait SJ, Poulton PR, Dunham SJ, McGrath SP (2008) Evidence of decreasing mineral density in wheat grain over the last 160 years. J Trace Elem Med Biol 22:315324

Flintham JE, Borner A, Worland AJ, Gale MD (1997) Optimizing wheat grain yield: Effects of $R h t$ (gibberellin-insensitive) dwarfing genes. J Agric Sci 128:11-25.

Garvin DF, Welch RM, Finley JW (2006) Historical shifts in the seed mineral micronutrient concentration of US hard red winter wheat germplasm. J Sci Food Agric 86:2213-2220

Gooding MJ (2009) The wheat crop. In: K Khan, P R Shewry (eds) Wheat: Chemistry and Technology, 4th edn. AACC International, Minnesota. pp 35-70.

Gooding MJ, Addisu M, Uppal RK, Snape JW, Jones HE (2012) Effect of wheat dwarfing genes on nitrogen use efficiency. J Agric Sci (available online June 2011 doi: 10.1017/S0021859611000414). 
Henderson L, Irving K, Gregory J, Bates CJ, Prentice A, Perks J, Swan G, Farron M (2003) The National Diet \& Nutrition Survey: adults aged 19 to 64 years, Volume 3. Her Majesty's Stationery Office, London

Kutman UB, Yildiz B, Cakmak I (2011a) Effect of nitrogen on uptake, remobilization and partitioning of zinc and iron throughout the development of durum wheat. Plant Soil 342:149-164

Kutman UB, Yildiz B, Cakmak I (2011b) Improved nitrogen status enhances zinc and iron concentrations both in the whole grain and the endosperm fraction of wheat. J Cereal Sci 53:118-125

Loddo S, Gooding MJ (2012) Semi-dwarfing (Rht-B1b) improves nitrogen-use efficiency in wheat, but not at economically optimal levels of nitrogen availability. Cereal Res Commun (accepted May 2011)

McDonald GK, Genc Y, Graham RD (2008) A simple method to evaluate genetic variation in grain zinc concentration by correcting for differences in grain yield. Plant Soil 306:49-55

McGrath SP (1985) The effects of increasing yields on the macroelement and microelement concentrations and offtakes in the grain of winter wheat. J Sci Food Agric 36:1073-1083

Morgounov A, Gomez-Becerra HF, Abugalieva A, Dzhunusova M, Yessimbekova M, Muminjanov H, Zelenskiy Y, Ozturk L, Cakmak I (2007) Iron and zinc grain density in common wheat grown in Central Asia. Euphytica 155:193-203

Murase K, Hirano Y, Sun TP, Hakoshima T (2008) Gibberellin-induced DELLA recognition by the gibberellin receptor GID1. Nature 456:459-U15

Oury FX, Leenhardt F, Remesy C, Chanliaud E, Duperrier B, Balfourier F, Charmet G (2006) Genetic variability and stability of grain magnesium, zinc and iron concentrations in bread wheat. Eur $\mathrm{J}$ Agron 25:177-185

Shi RL, Zhang YQ, Chen XP, Sun QP, Zhang FS, Römheld V, Zou CQ (2010) Influence of long-term nitrogen fertilization on micronutrient density in grain of winter wheat (Triticum aestivum L.). $\mathrm{J}$ Cereal Sci 51:165-170

Sylvester-Bradley R, Kindred DR 2009 Analysing nitrogen response of cereals to prioritize routes to the improvement of nitrogen use efficiency. J Exp Bot 60:1939-1951

White PJ, Broadley MR (2005) Historical variation in the mineral composition of edible horticultural products. J Hort Sci Biotech 80:660-667.

White PJ, Broadley MR (2009) Biofortification of crops with seven mineral elements often lacking in human diets - iron, zinc, copper, calcium, magnesium, selenium and iodine. New Phytol 182:49-84 WHO (2002) The World Health Report (2002) Reducing risks, promoting healthy life. pp 1-230. World Health Organization, Geneva, Switzerland. 
447 Zadoks JC, Chang TT, Konzak CF (1974) A decimal code for the growth stages of cereals. Weed Res $448 \quad 44: 415-421$

449 Zhao F, McGrath SP, Crosland AR (1994) Comparison of three wet digestion methods for the 450 determination of plant sulphur by inductively coupled plasma atomic emission spectroscopy (ICP451 AES). Commun Soil Sci Plant Anal 25:407-418

452 Zhao FJ, Su YH, Dunham SJ, Rakszegi M, Bedo Z, McGrath SP, Shewry PR (2009) Variation in mineral 453 micronutrient concentrations in grain of wheat lines of diverse origin. J Cereal Sci 49:290-295

454 
Table 1 Monthly weather data, soil analyses, and crop husbandry common to all treatments for the two field plot experiments

\begin{tabular}{|c|c|c|c|c|c|c|c|}
\hline & & \multicolumn{2}{|c|}{2010} & \multicolumn{2}{|c|}{2011} & \multicolumn{2}{|c|}{$\begin{array}{c}\text { Long term average ( } 47 \\
\text { years) }\end{array}$} \\
\hline & & $\overline{\text { Rainfall }(\mathrm{mm})}$ & $\begin{array}{l}\text { Mean temp. } \\
\left({ }^{\circ} \mathrm{C}\right)\end{array}$ & Rainfall (mm) & $\begin{array}{l}\text { Mean temp. } \\
\left({ }^{\circ} \mathrm{C}\right)\end{array}$ & $\begin{array}{c}\text { Rainfall } \\
(\mathrm{mm})\end{array}$ & $\begin{array}{c}\text { Mean } \\
\text { temp. }\left({ }^{\circ} \mathrm{C}\right)\end{array}$ \\
\hline March & & 46.2 & 6.3 & 13.8 & 6.5 & 47.2 & 6.5 \\
\hline April & & 22.0 & 9.2 & 2.8 & 12.2 & 47.9 & 8.7 \\
\hline May & & 12.0 & 11.2 & 30.0 & 12.3 & 47.9 & 12.0 \\
\hline June & & 20.8 & 16.1 & 89.8 & 14.2 & 49.3 & 15.0 \\
\hline July & & 31.6 & 18.4 & 41.1 & 16.2 & 44.6 & 17.2 \\
\hline August & & 108.0 & 16.1 & 125.2 & 15.9 & 60.1 & 17.0 \\
\hline $\begin{array}{l}\text { Treatment or } \\
\text { operation }\end{array}$ & $\begin{array}{c}\text { Growth stage (GS, } \\
\text { Zadoks et al. } \\
1974) \\
\end{array}$ & & & & & & \\
\hline \multicolumn{8}{|l|}{ Soil test $0-90 \mathrm{~cm}$} \\
\hline $\mathrm{pH}$ & & 6 & & 6. & & & \\
\hline P mg/l (index) & & $49 .($ & (4) & 26.4 & & & \\
\hline K mg/l (index) & & 99 & & 88( & & & \\
\hline Mg mg/l (ind.) & & 48 & & 52( & & & \\
\hline Herbicide & $\begin{array}{l}\text { Destruction of } \\
\text { previous sward }\end{array}$ & \multicolumn{4}{|c|}{ Glyphosate $1.8 \mathrm{~kg} / \mathrm{ha}$} & & \\
\hline Sub-soiled & Pre-ploughing & $16 \mathrm{Sep}$ & ember & Not app & icable & & \\
\hline Nutrition & Pre-ploughing & $120 \mathrm{~kg} / \mathrm{ha} \mathrm{K}{ }_{2}$ & equ. as $\mathrm{KCl}$ & $90 \mathrm{~kg} / \mathrm{ha} \mathrm{K} \mathrm{K}_{2} \mathrm{O}$ & equ. as $\mathrm{KCl}$ & & \\
\hline Ploughed & & $8 \mathrm{Oc}$ & ober & 23 Sept & ember & & \\
\hline Harrowed & & $21 \mathrm{O}$ & tober & 8 Oct & ber & & \\
\hline Drilled & & $22 \mathrm{O}$ & tober & 8 Oct & ber & & \\
\hline Rolled & & $22 \mathrm{O}$ & tober & $11 \mathrm{Oct}$ & ober & & \\
\hline Herbicide & 13 & \multicolumn{4}{|c|}{$\begin{array}{c}1.2 \mathrm{~kg} / \mathrm{ha} \text { pendimethalin }+20 \mathrm{~g} / \mathrm{ha} \text { carfentrazone-ethyl }+10 \\
\mathrm{~g} / \text { ha flupyrsulfuron-methyl }\end{array}$} & & \\
\hline Nutrition & 30 & $40 \mathrm{~kg} / \mathrm{ha} \mathrm{SO}_{3}$ & qu. as $\mathrm{K}_{2} \mathrm{SO}_{4}$ & $32 \mathrm{~kg} / \mathrm{ha} \mathrm{SO}_{3} \mathrm{e}$ & qu. as $\mathrm{K}_{2} \mathrm{SO}_{4}$ & & \\
\hline Herbicide & 31 & \multicolumn{4}{|c|}{$50 \mathrm{~g} /$ ha thifensulfuron-methyl $+5 \mathrm{~g} /$ ha metsulfuron-methyl } & & \\
\hline Fungicide & 32 & $\begin{array}{r}125 \mathrm{~g} / \mathrm{ha} \mathrm{epo} \\
150 \mathrm{~g} / \mathrm{ha} \mathrm{qu} \\
\mathrm{kg} / \mathrm{ha} \mathrm{chlc}\end{array}$ & $\begin{array}{l}\text { xiconazole }+ \\
\text { noxyfen }+1 \\
\text { rothalonil }\end{array}$ & $\begin{array}{r}125 \mathrm{~g} / \mathrm{ha} \text { epox } \\
150 \mathrm{~g} / \mathrm{ha} \text { metr } \\
\mathrm{kg} / \mathrm{ha} \text { chlor }\end{array}$ & $\begin{array}{l}\text { iconazole }+ \\
\text { afenone }+1 \\
\text { othalonil }\end{array}$ & & \\
\hline Fungicide & 39 & \multicolumn{4}{|c|}{$125 \mathrm{~g} /$ ha epoxiconazole $+250 \mathrm{~g} / \mathrm{ha}$ azoxystrobin } & & \\
\hline Fungicide & 59 & \multicolumn{4}{|c|}{$250 \mathrm{~g} /$ ha tebuconazole } & & \\
\hline Insecticide & 59 & \multicolumn{4}{|c|}{$5 \mathrm{~g} /$ ha deltamethrin } & & \\
\hline Harvest & & \multicolumn{2}{|c|}{9 August } & \multicolumn{2}{|c|}{17 August } & & \\
\hline
\end{tabular}


Table 2 The effect of allele at the Rht-B1 locus and nitrogen fertilizer application rate $(\mathrm{N}, \mathrm{kg} / \mathrm{ha})$ on the final crop height $(\mathrm{mm})$ of winter wheat.

\begin{tabular}{|c|c|c|c|c|c|c|c|}
\hline \multicolumn{4}{|c|}{$\begin{array}{l}2010 \text { (Mean of Maris Huntsman, Maris } \\
\text { Widgeon and Mercia backgrounds) }\end{array}$} & \multicolumn{4}{|c|}{$\begin{array}{c}2011 \text { (Mean of Maris Widgeon and Mercia } \\
\text { backgrounds) }\end{array}$} \\
\hline $\mathrm{N}$ & Bla & $B 1 b$ & $B 1 c$ & $\mathrm{~N}$ & Bla & $B 1 b$ & $B 1 c$ \\
\hline 0 & 910 & 720 & 420 & 0 & 840 & 700 & 450 \\
\hline 100 & 1020 & 830 & 460 & 50 & 850 & 720 & 460 \\
\hline 200 & 1020 & 840 & 480 & 100 & 830 & 700 & 440 \\
\hline \multirow[t]{3}{*}{350} & 1000 & 830 & 470 & 200 & 820 & 730 & 440 \\
\hline & & & & 350 & 830 & 750 & 460 \\
\hline & & & & 450 & 810 & 740 & 450 \\
\hline S.E.D. ${ }^{a}$ & & & 11 & & & & 13 \\
\hline d.f. & & & 54 & & & & 55 \\
\hline Mean & 990 & 810 & 460 & & 830 & 720 & 450 \\
\hline S.E.D. ${ }^{b}$ & & & 12 & & & & 19 \\
\hline d.f. & & & 16 & & & & 10 \\
\hline
\end{tabular}


Table 3 Effect of cultivar on the height, yields and partitioning of dry matter and minerals in winter wheat.

\begin{tabular}{|c|c|c|c|c|c|c|c|}
\hline & \multicolumn{4}{|l|}{2010} & \multicolumn{3}{|l|}{2011} \\
\hline & $\begin{array}{l}\text { Maris } \\
\text { Hunts- } \\
\text { man }\end{array}$ & Mercia & $\begin{array}{c}\text { Maris } \\
\text { Widg- } \\
\text { eon }\end{array}$ & $\begin{array}{l}\text { S.E.D. } \\
\text { (16 d.f.) }\end{array}$ & Mercia & $\begin{array}{l}\text { Maris } \\
\text { Widg- } \\
\text { eon }\end{array}$ & $\begin{array}{l}\text { S.E.D. } \\
\text { (10 d.f.) }\end{array}$ \\
\hline Crop height (mm) & 1010 & 820 & 1120 & 20 & 750 & 910 & 27 \\
\hline $\begin{array}{l}\text { Dry Matter } \\
\text { Above ground crop }(\mathrm{t} / \mathrm{ha}) \\
\text { Harvest_index } \\
\text { Grain yield (t/ha) } \\
\text { Mass per grain }(\mathrm{mg})\end{array}$ & $\begin{array}{c}13.9 \\
0.47 \\
6.85 \\
49.5\end{array}$ & $\begin{array}{c}13.0 \\
0.47 \\
6.23 \\
40.7\end{array}$ & $\begin{array}{c}15.0 \\
0.39 \\
5.82 \\
48.9\end{array}$ & $\begin{array}{l}1.23 \\
0.013 \\
0.535 \\
1.28\end{array}$ & $\begin{array}{l}9.9 \\
0.54 \\
5.33 \\
54.8\end{array}$ & $\begin{array}{c}8.8 \\
0.48 \\
4.24 \\
59.1\end{array}$ & $\begin{array}{l}1.50 \\
0.007 \\
0.556 \\
0.74\end{array}$ \\
\hline $\begin{array}{l}\text { Copper }(\mathrm{Cu}) \\
\text { Above ground crop }\left(\mathrm{mg} / \mathrm{m}^{2}\right) \\
\text { Harvest_index } \\
\text { Grain yield }\left(\mathrm{mg} / \mathrm{m}^{2}\right) \\
\text { Mass per grain }(\mu \mathrm{g}) \\
\text { Grain concentration }(\mathrm{mg} / \mathrm{kg})\end{array}$ & $\begin{array}{l}4.32 \\
0.70 \\
3.10 \\
0.22 \\
4.52\end{array}$ & $\begin{array}{l}3.85 \\
0.63 \\
2.41 \\
0.16 \\
3.87\end{array}$ & $\begin{array}{l}4.25 \\
0.60 \\
2.54 \\
0.21 \\
4.32\end{array}$ & $\begin{array}{l}0.411 \\
0.021 \\
0.201 \\
0.006 \\
0.133\end{array}$ & $\begin{array}{l}2.88 \\
0.66 \\
1.91 \\
0.20 \\
3.60\end{array}$ & $\begin{array}{l}2.96 \\
0.62 \\
1.88 \\
0.26 \\
4.42\end{array}$ & $\begin{array}{l}0.439 \\
0.011 \\
0.199 \\
0.006 \\
0.105\end{array}$ \\
\hline $\begin{array}{l}\text { Iron }(\mathrm{Fe}) \\
\text { Above ground crop }\left(\mathrm{mg} / \mathrm{m}^{2}\right) \\
\text { Harvest_index } \\
\text { Grain yield }\left(\mathrm{mg} / \mathrm{m}^{2}\right) \\
\text { Mass per grain }(\mu \mathrm{g}) \\
\text { Grain concentration }(\mathrm{mg} / \mathrm{kg})\end{array}$ & $\begin{array}{l}53.4 \\
0.41 \\
20.6 \\
1.42 \\
28.8\end{array}$ & $\begin{array}{l}51.8 \\
0.36 \\
18.5 \\
1.16 \\
28.7\end{array}$ & $\begin{array}{l}57.6 \\
0.33 \\
18.3 \\
1.48 \\
30.1\end{array}$ & $\begin{array}{l}7.02 \\
0.026 \\
1.88 \\
0.068 \\
1.23\end{array}$ & $\begin{array}{c}184.1 \\
0.11 \\
15.8 \\
1.61 \\
29.2\end{array}$ & $\begin{array}{c}184.9 \\
0.09 \\
12.7 \\
1.75 \\
29.5\end{array}$ & $\begin{array}{l}9.90 \\
0.013 \\
1.68 \\
0.057 \\
0.99\end{array}$ \\
\hline $\begin{array}{l}\text { Magnesium }(\mathrm{Mg}) \\
\text { Above ground crop }\left(\mathrm{g} / \mathrm{m}^{2}\right) \\
\text { Harvest_index } \\
\text { Grain yield }\left(\mathrm{g} / \mathrm{m}^{2}\right) \\
\text { Mass per grain }(\mu \mathrm{g}) \\
\text { Grain concentration }(\mathrm{g} / \mathrm{kg})\end{array}$ & $\begin{array}{c}1.13 \\
0.59 \\
0.68 \\
50.0 \\
1.01\end{array}$ & $\begin{array}{c}1.03 \\
0.59 \\
0.61 \\
40.4 \\
0.99\end{array}$ & $\begin{array}{c}1.15 \\
0.52 \\
0.59 \\
49.9 \\
1.02\end{array}$ & $\begin{array}{l}0.119 \\
0.013 \\
0.046 \\
1.00 \\
0.022\end{array}$ & $\begin{array}{c}0.96 \\
0.63 \\
0.60 \\
61.3 \\
1.12\end{array}$ & $\begin{array}{c}0.80 \\
0.58 \\
0.46 \\
64.4 \\
1.09\end{array}$ & $\begin{array}{l}0.164 \\
0.028 \\
0.062 \\
1.11 \\
0.014\end{array}$ \\
\hline $\begin{array}{l}\text { Zinc }(\mathrm{Zn}) \\
\text { Above ground crop }\left(\mathrm{mg} / \mathrm{m}^{2}\right) \\
\text { Harvest_index } \\
\text { Grain yield }\left(\mathrm{mg} / \mathrm{m}^{2}\right) \\
\text { Mass per grain }(\mu \mathrm{g}) \\
\text { Grain concentration }(\mathrm{mg} / \mathrm{kg})\end{array}$ & $\begin{array}{c}15.6 \\
0.85 \\
13.3 \\
0.97 \\
19.6\end{array}$ & $\begin{array}{c}14.6 \\
0.85 \\
12.2 \\
0.80 \\
19.8\end{array}$ & $\begin{array}{c}16.1 \\
0.79 \\
12.6 \\
1.07 \\
21.9\end{array}$ & $\begin{array}{l}1.63 \\
0.017 \\
1.09 \\
0.035 \\
0.86\end{array}$ & $\begin{array}{c}12.4 \\
0.92 \\
11.2 \\
1.15 \\
20.9\end{array}$ & $\begin{array}{c}11.6 \\
0.90 \\
10.2 \\
1.42 \\
24.0\end{array}$ & $\begin{array}{l}1.52 \\
0.008 \\
1.02 \\
0.063 \\
1.16\end{array}$ \\
\hline
\end{tabular}


Table 4 The effect of allele at the Rht-Bl locus on the fitted economically optimal level of nitrogen $\left(N_{\text {opt }}\right)$ for two N:Grain price ratios, and the fitted (Figs. $1 \& 3$ ) mineral concentrations at $N_{\text {opt }}$.

\begin{tabular}{|c|c|c|c|c|c|c|}
\hline \multirow{2}{*}{$\begin{array}{l}\mathrm{N} \text { :Grain price } \\
\text { ratio }\end{array}$} & \multicolumn{3}{|c|}{2010} & \multicolumn{3}{|c|}{2011} \\
\hline & $B 1 a$ & $B 1 b$ & $B 1 c$ & $B 1 a$ & $B 1 b$ & $B 1 c$ \\
\hline \multicolumn{7}{|l|}{$\mathrm{N}_{o p t}(\mathrm{~kg} / \mathrm{ha})$} \\
\hline $5.0: 1$ & 253 & 299 & 243 & 115 & 179 & 97 \\
\hline 10.0:1 & 213 & 252 & 197 & 0 & 0 & 0 \\
\hline \multicolumn{7}{|c|}{ Grain yield at $\mathrm{N}_{o p t}$} \\
\hline $5.0: 1$ & 7.8 & 9.2 & 7.3 & 4.7 & 4.9 & 4.9 \\
\hline $10.0: 1$ & 7.6 & 9.0 & 7.1 & 4.1 & 3.9 & 4.4 \\
\hline \multicolumn{7}{|c|}{$\mathrm{mg} \mathrm{Cu} / \mathrm{kg}$ at $\mathrm{N}_{o p t}$} \\
\hline $5.0: 1$ & 4.3 & 4.0 & 4.9 & 4.2 & 4.3 & 4.2 \\
\hline 10.0:1 & 4.3 & 4.0 & 4.8 & 3.8 & 3.9 & 4.1 \\
\hline \multicolumn{7}{|c|}{$\mathrm{mg} \mathrm{Fe} / \mathrm{kg}$ at $\mathrm{N}_{o p t}$} \\
\hline $5.0: 1$ & 33.9 & 30.4 & 33.9 & 28.9 & 30.7 & 28.3 \\
\hline $10.0: 1$ & 32.8 & 29.3 & 31.8 & 24.0 & 24.0 & 24.0 \\
\hline \multicolumn{7}{|l|}{$\mathrm{g} \mathrm{Mg} / \mathrm{kg}$ at $\mathrm{N}_{\text {opt }}$} \\
\hline $5.0: 1$ & 1.01 & 0.88 & 0.88 & 1.10 & 1.10 & 1.01 \\
\hline $10.0: 1$ & 1.00 & 0.87 & 0.88 & 1.05 & 1.02 & 0.97 \\
\hline \multicolumn{7}{|c|}{$\mathrm{mg} Z \mathrm{Zn} / \mathrm{kg}$ at $\mathrm{N}_{o p t}$} \\
\hline $5.0: 1$ & 19.6 & 17.4 & 20.4 & 21.5 & 22.7 & 21.2 \\
\hline 10.0:1 & 19.5 & 16.9 & 19.8 & 18.8 & 18.8 & 18.8 \\
\hline
\end{tabular}

465 


\section{Figures:}

Fig. 1 Effect of nitrogen and allele at the Rht-Bl locus on yield and mineral content of winter wheat near isogenic lines. $\square=r h t-B 1 a$ (tall); $\triangle=R h t-B 1 b$ (semi-dwarf); $\circ$, dashed line $=R h t-B 1 c$ (severe dwarf).

Points are means of three replicate blocks and three wheat backgrounds (Maris Huntsman, Mercia, Maris Widgeon). Left and right error bars are S.E.D. for comparing between and within alleles respectively (sub plot error d.f. $=53$ ). Main and interacting effects of Allele, Linear $\mathrm{N}$ and Quadratic $\mathrm{N}$ only fitted if effect is statistically significant $(P<0.05)$.

Fig. 2 Relationships between grain mineral concentration and grain nitrogen concentration in wheat harvested in 2010 (left) and 2011 (right). Points are means of three replicate blocks and wheat backgrounds (Mercia, Maris Huntsman and Maris Widgeon in 2010; Mercia and Maris Widgeon in 2011), and vary for allele as near isogenic lines at the $R h t-B 1$ locus ( $\square=r h t-B 1 a$ (tall); $\triangle=R h t-B 1 b$ (semi-dwarf); $\circ$, dashed line $=R h t-B 1 c$ (severe dwarf)) and for nitrogen fertilizer application rate $(\mathrm{N}$ rate). Numerals above inverted triangles in Fe panels are the $\mathrm{N}$ rates $(\mathrm{kg} / \mathrm{ha})$ associated with the nitrogen concentrations achieved (averaged over allele). Error bars are maximum S.E.D. for comparing points (sub plot error d.f. $=53$ and 55 for 2010 and 2011 respectively). Main and interacting effects of Allele, Linear $\mathrm{N}$ and Quadratic N only fitted if effect is statistically significant $(P<0.05)$.

Fig. 3 Effect of nitrogen and allele at the Rht-Bl locus on yield and mineral content of winter wheat near isogenic lines harvested in 2011. $\square=r h t-B 1 a$ (tall); $\triangle=R h t-B 1 b$ (semi-dwarf); $\circ$, dashed line $=R h t-B 1 c$ (severe dwarf). Points are means of three replicate blocks and two wheat backgrounds (Mercia, Maris Widgeon). Left and right error bars are S.E.D. for comparing between and within alleles respectively (sub plot error d.f. $=55$ ). Main and interacting effects of Allele, Linear $\mathrm{N}$ and Quadratic $\mathrm{N}$ only fitted if effect is statistically significant $(P<0.05)$.

Fig. 4 Effects of dwarfing alleles in the Maris Huntsman background on grain yield and height (a), grain micronutrient concentrations (b), uptake (c) and harvest indices in the pot experiment. Error bars are S.E.D. $($ d.f. $=12)$ for comparing different alleles; the error bars from left to right in each graph correspond to the variable from top to bottom in the legend box.

Fig. 5 Correlation between grain $\mathrm{Fe}, \mathrm{Zn}$ or $\mathrm{Cu}$ concentrations and grain yield in the pot experiment. 

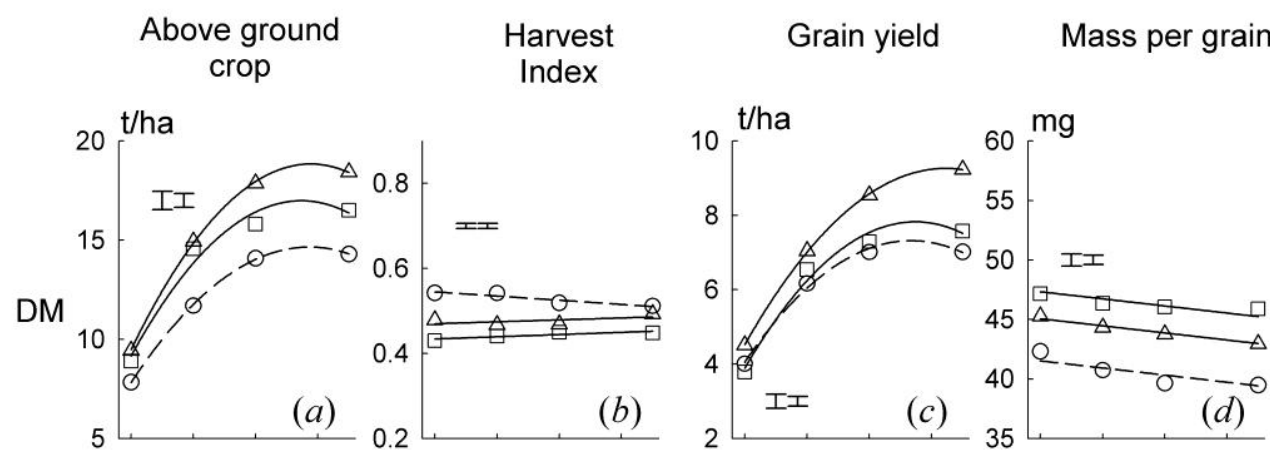

Mass per grain

Grain

concentration
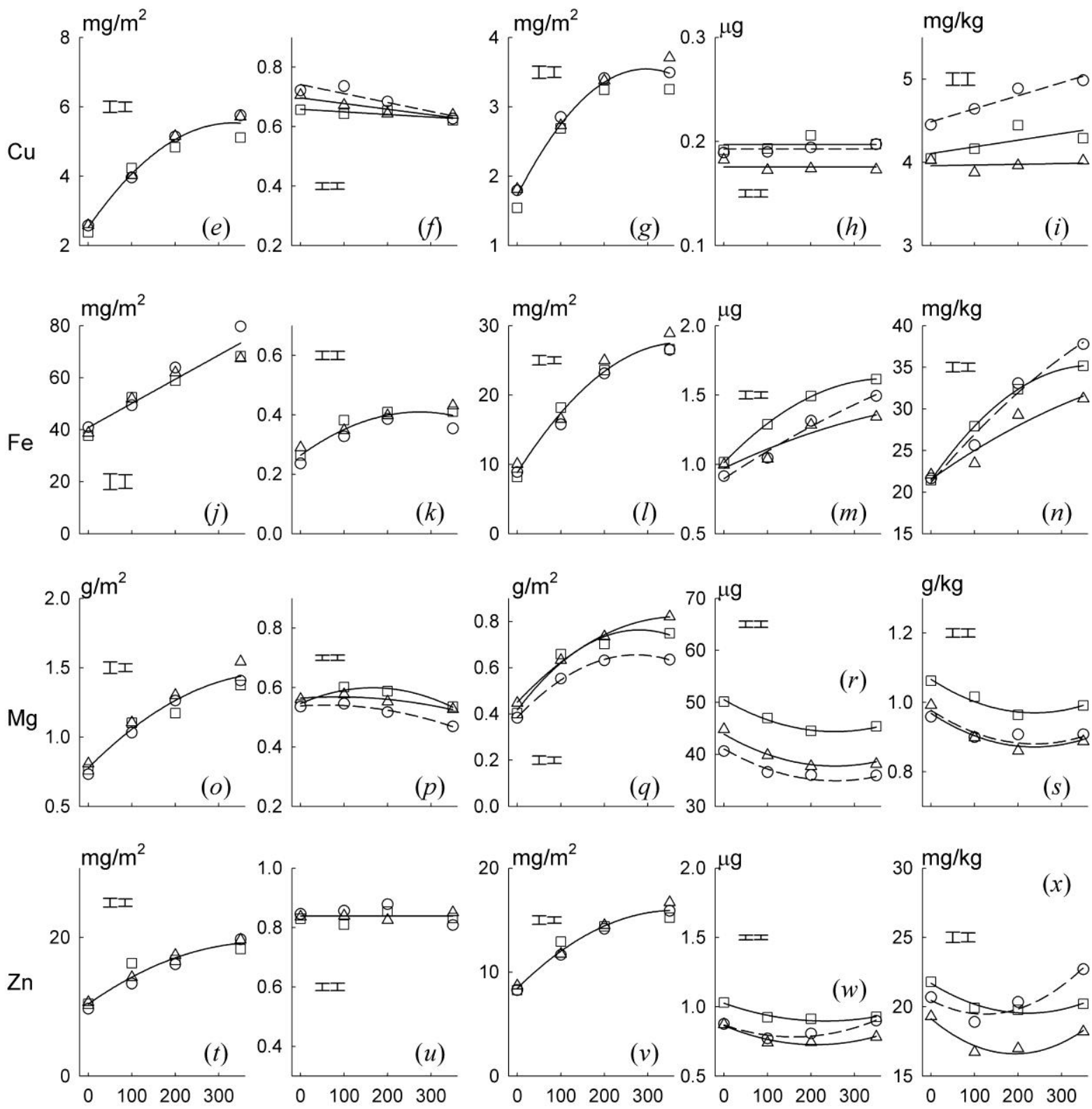

Figure 1. 

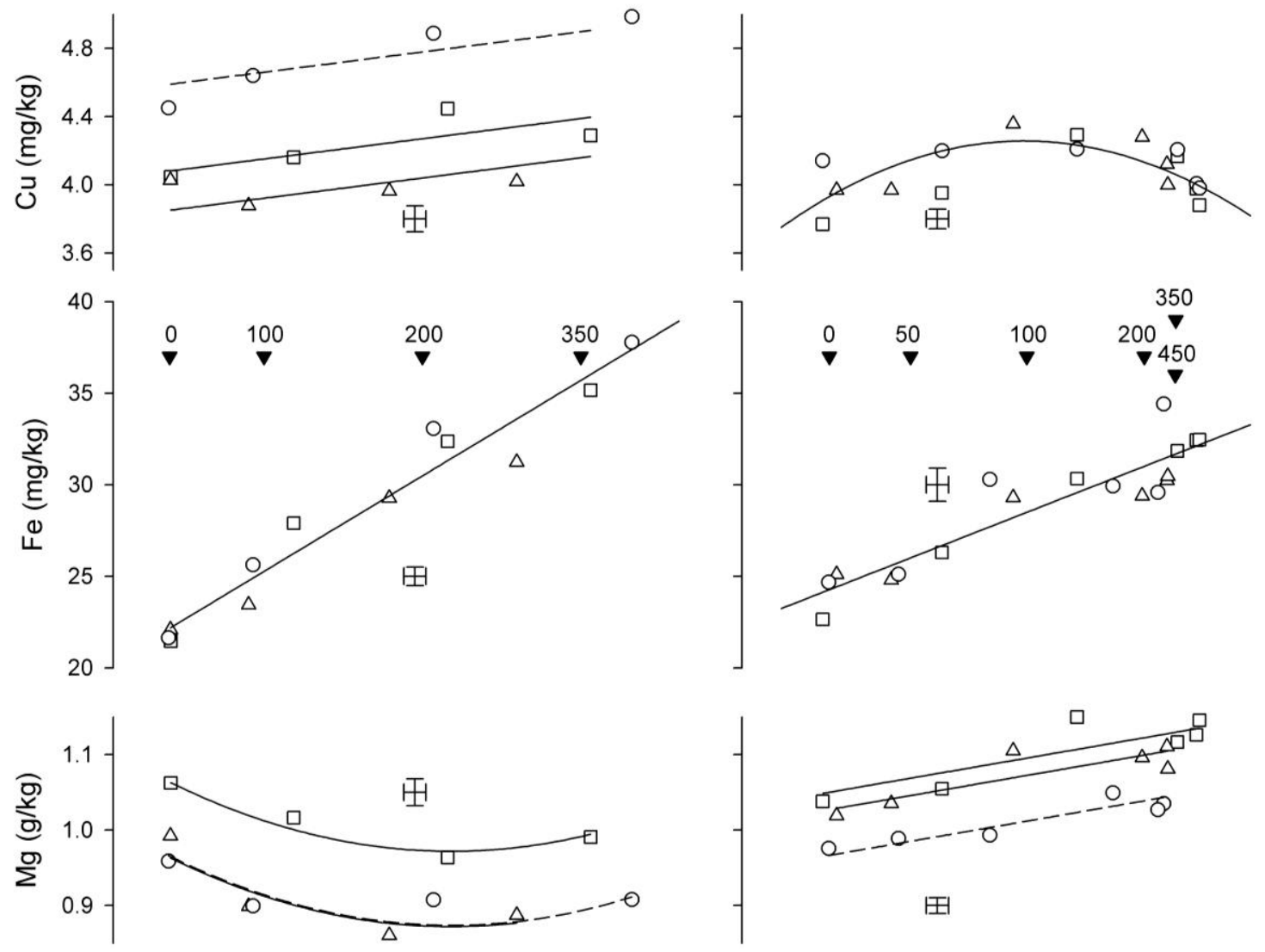

玨

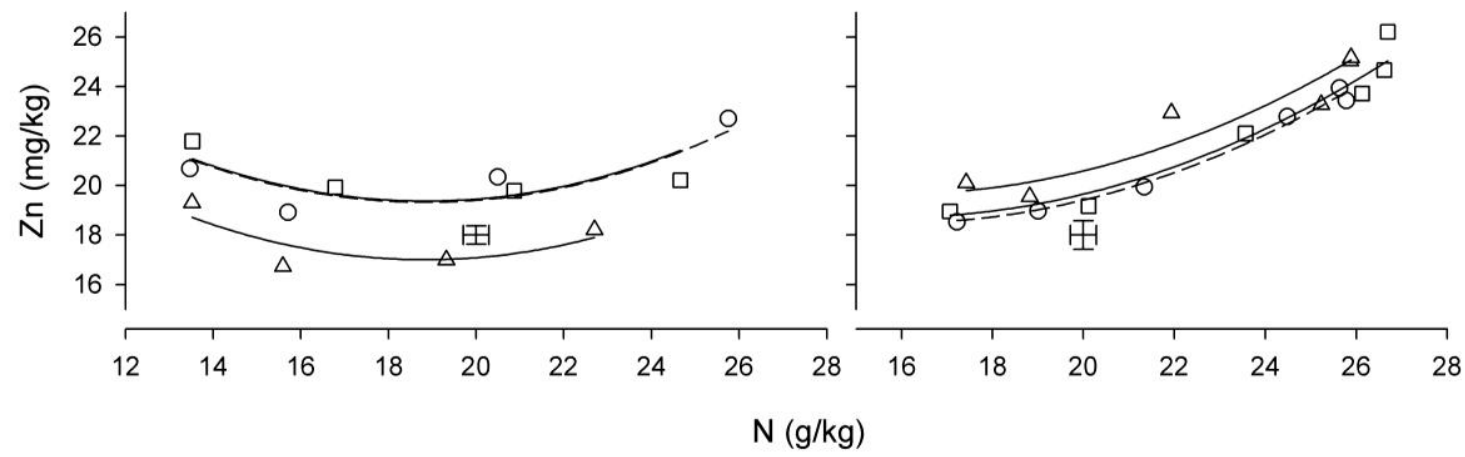

497

$498 \quad$ Figure 2.

499 

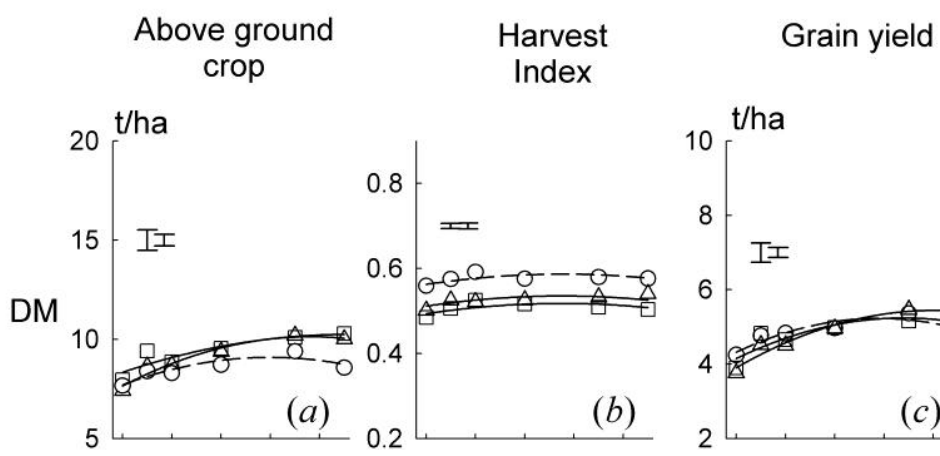

Mass per grain

Grain

concentration
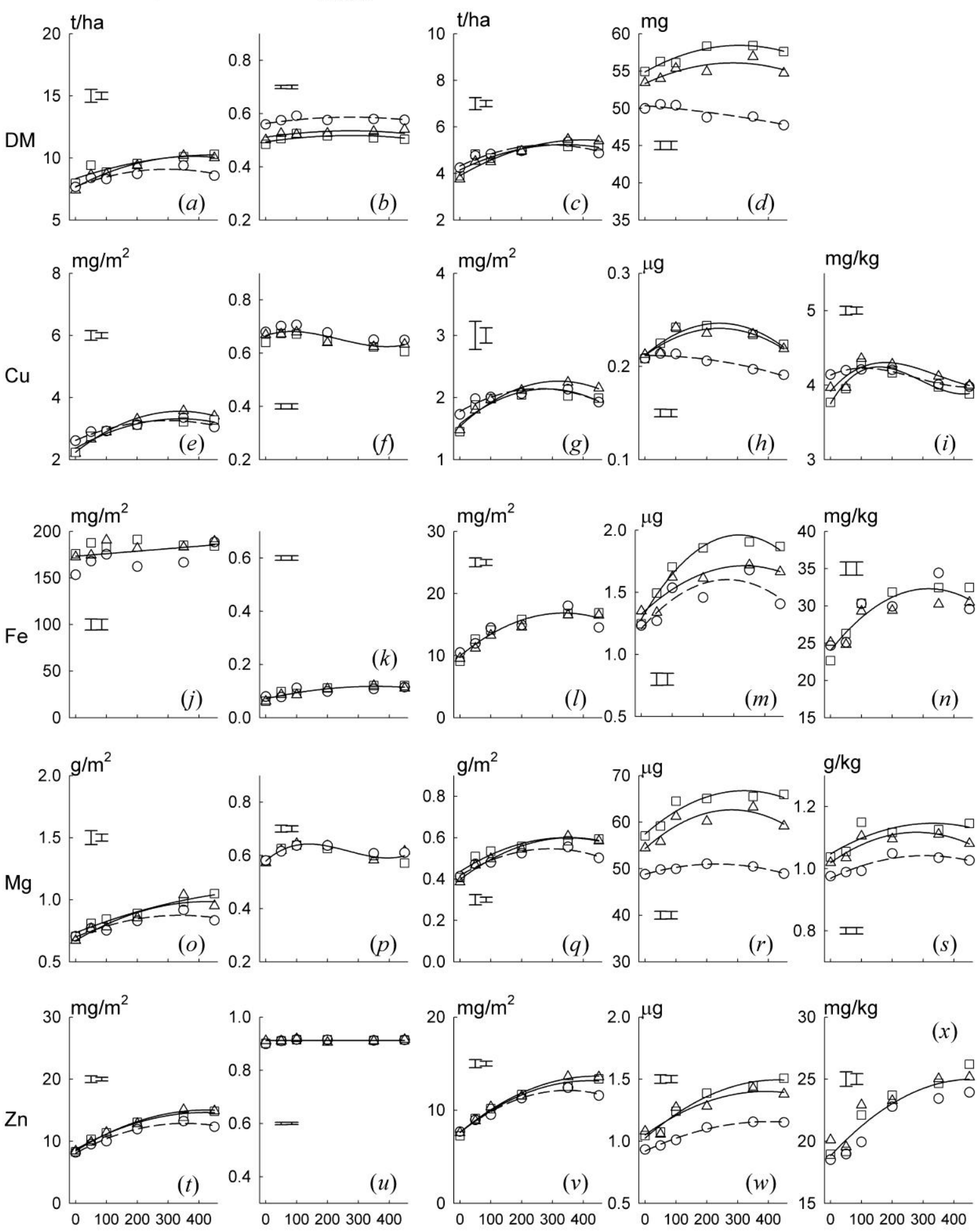

501 Figure 3. 

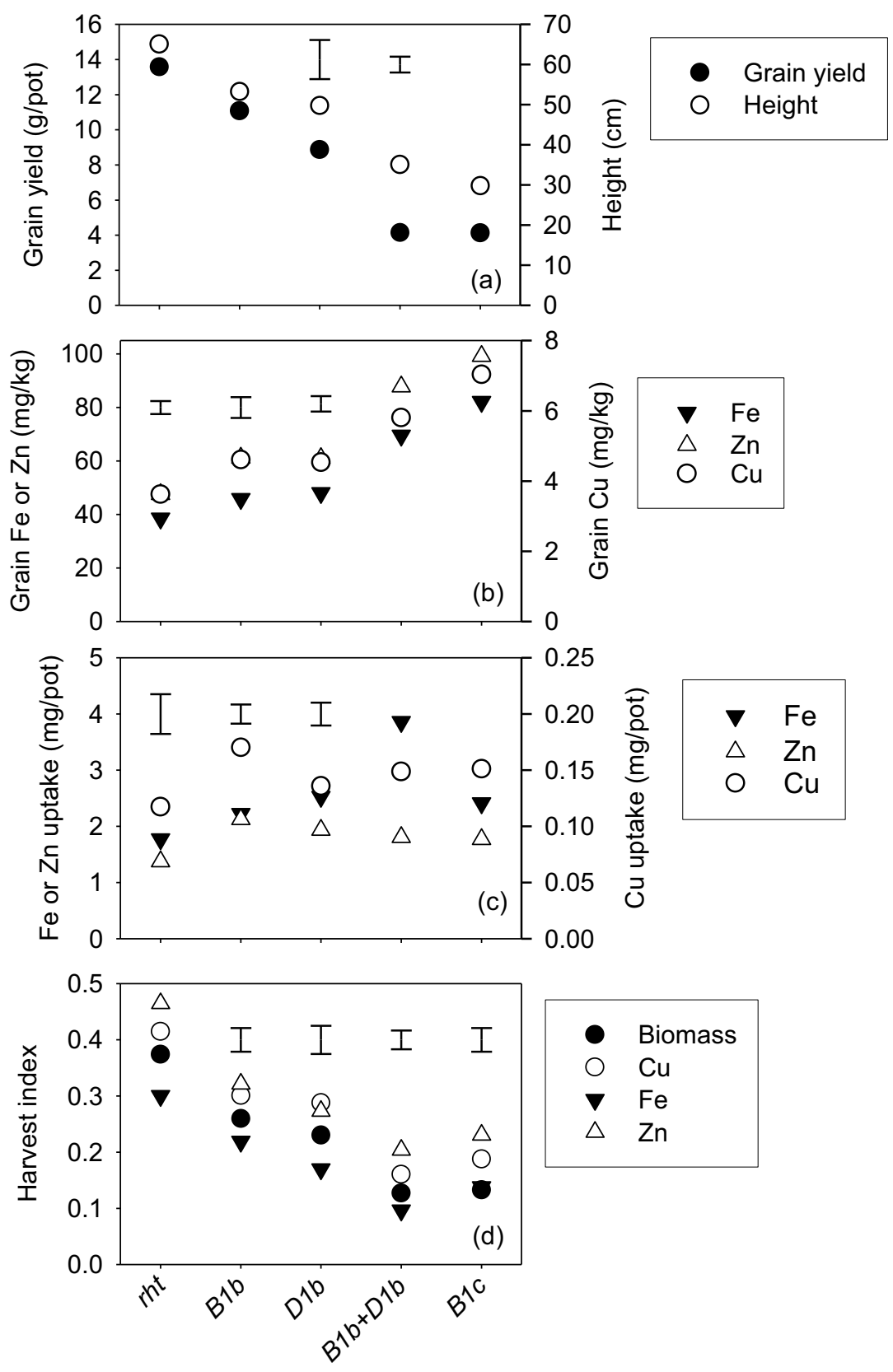

502

503 Figure 4. 


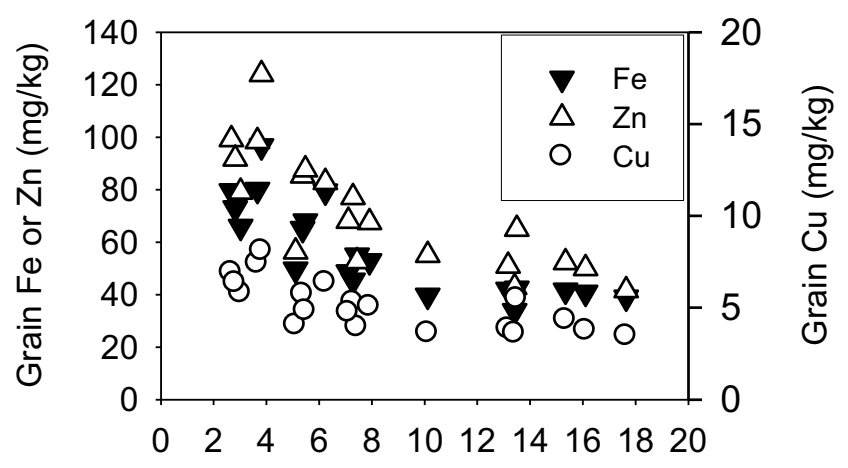

506

Grain yield (g/pot)

507 Figure 5. 